\title{
Evaluasi Fisik Organoleptik Multinutrien Blok yang dibuat dengan Metode Panas pada Penambahan Level Molases yang Berbeda
}

\author{
Dyah Ayu Putri Rusmala Dewi, Retno Iswarin Pujaningsih dan \\ Agung Subrata \\ Departemen Peternakan, Fakultas Peternakan dan Pertanian, Universitas \\ Diponegoro, Kompl. drh. R. Soejono Koesoemowardojo, Tembalang \\ Semarang Kode Pos 50275 \\ E-mail: dyahayu.prd@gmail.com
}

\begin{abstract}
ABSTRAK
Penelitian bertujuan untuk mengevaluasi pengaruh penambahan level molases terhadap kualitas fisik dan organoleptik pada Multinutrien Blok $(\mathrm{MnB})$ yang dibuat dengan metode panas. Materi yang digunakan dalam penelitian adalah molases, hijauan jagung, garam, cangkang kerang darah, cangkang telur, urea dan bentonit. Alat yang digunakan yaitu chopper, disc mill, palu, kompor, panci, ember, cetakan MNB, timbangan digital dan kuesioner. Rancangan percobaan yang digunakan yaitu rancangan acak lengkap dengan 4 perlakuan dan 4 ulangan (T0 : tanpa penambahan molases (kontrol), T1 : penambahan molases sebanyak 20\%, T2 : penambahan molases sebanyak 35\% dan T3 : penambahan molases sebanyak 50\%). Parameter yang diamati yaitu kualitas fisik (kadar air) dan kualitas organoleptik (warna, tekstur dan aroma) pada Multinutrien Blok. Data analisis menggunakan analisis ragam dan dilanjutkan dengan uji lanjut wilayah ganda Duncan. Hasil penelitian menunjukkan bahwa penambahan level molases berpengaruh nyata $(\mathrm{P}<0,05)$ terhadap warna, tekstur dan aroma. Perlakuan T3 pada pengujian warna, tekstur dan aroma memiliki nilai paling tinggi yaitu 3,99; 3,55 dan 3,32. Kadar air menunjukan tidak berpengaruh nyata. Simpulan dari penelitian ini adalah penambahan level molases sebesar 50\% menghasilkan kualitas fisik dan organoleptik paling baik pada pembuatan Multinutrien Blok dengan metode panas.

Kata kunci : Multinutrien blok, kualitas fisik, organoleptik, molasses.
\end{abstract}

\begin{abstract}
The research aims to evaluate the effect of adding molasses levels to the physical and organoleptic quality of multinutrient blocks $(\mathrm{MnB})$ made by the heat method. The material used in this research are molasses, forage corn, salt, blood shells, eggshell, urea and bentonite. The tools used are chopper, disc mill, hammer, stove, pan, bucket, MNB mold, digital scale and questionnaire. The experimental design used was complete random design with 4 treatments and 4 replications (T0: without addition of molasses (control), T1: addition of molasses by 20\%, T2: addition of molasses by 35\% and T3: addition of molasses by 50\%). The parameters observed were physical quality (water content) and organoleptic quality (color, texture and aroma) in Block Multinutrients. Data analysis used analysis of variance and continued with Duncan's multiple region test. The results showed that the addition of molasses level had a significant effect $(P<0.05)$ on color, texture and aroma. T3 treatment on color, texture and aroma testing has the highest value, namely 3.99; 3.55 and 3.32. Moisture content shows no significant effect. The conclusion of this research is the addition of molasses level by $50 \%$ produces the best physical and organoleptic quality in the manufacture of Block Multinutrients by the heat method.
\end{abstract}

Keywords : Multinutrien block, physicals quality, oragnoleptics, molasses. 


\section{PENDAHULUAN}

Pakan merupakan salah satu aspek penting dalam usaha peternakan yang sangat mempengaruhi produktivitas ternak. Kualitas maupun kuantitas pakan yang rendah, dapat mengakibatkan turunnya produktivitas ternak. Peternak tradisional biasanya hanya memberikan pakan berupa hijauan dengan kualitas rendah yang belum mampu memenuhi kebutuhan nutrien ternak. Salah satu cara agar kebutuhan nutrien ternak terpenuhi yaitu dengan pemberian pakan pelengkap.

Strategi perbaikan nutrien untuk ternak dapat dilakukan dengan melakukan suplementasi nutrien yang mengandung energi, protein dan mineral. Suplementasi yang sudah dilakukan yaitu dengan pemberian urea molases multinutrien blok (UMMB) yang terdiri dari beberapa bahan pakan diantaranya urea, molases, wheat bran, garam, semen dan beberapa campuran mineral (Tanwar et al., 2013). Bahan sumber mineral yang digunakan dalam pembuatan UMMB berasal dari mineral anorganik yang harganya cenderung lebih mahal, sehingga diperlukan bahan organik sebagai alternatif untuk sumber mineral. Oleh karena itu salah satu suplementasi pakan dapat diberikan dalam bentuk multinutrien blok $(\mathrm{MnB})$ yang bertujuan untuk memenuhi nutrien utama dan kebutuhan mineral pada ternak dengan menggunakan bahan-bahan organik sebagai bahan penyusunnya.

Multinutrien Blok merupakan pakan pelengkap yang terdiri dari bahan-bahan yang murah, mudah didapat dan tidak bersaing dengan manusia. Pemberian $\mathrm{MnB}$ sebagai pakan pelengkap pada kambing berguna untuk mencukupi kebutuhan nutrien, meningkatkan nafsu makan, sumber energi agar produktivitas dapat meningkat. Suplementasi nutrien merupakan modifikasi dari beberapa bahan pakan yang dibuat dengan komposisi nutrien tertentu untuk mencukupi kebutuhan ternak (Putri, 2006). Keuntungan lain dari MnB yaitu dapat dijadikan solusi saat musim kemarau yaitu disaat kualitas dan kuantitas hijauan segar rendah sehingga kebutuhan nutrien ternak tetap tercukupi dan dapat meningkatkan produktivitas ternak (Preston dan Leng, 1987).

Kualitas MnB yang baik dapat dilihat dari kadar air, karena aspek tersebut dapat mempengaruhi lama penyimpanan dan kemampuan MnB untuk tetap mempertahankan bentuknya yang utuh saat distribusi. Kualitas MnB juga ditentukan oleh jenis serta jumlah penggunaan binder yang tepat. Salah satu jenis binder yang sudah sering digunakan dalam pembuatan mineral blok dan konsentrat yaitu molases. Syarat penggunaan binder diantaranya yaitu mudah didapat, murah, tidak bersaing dengan manusia dan tidak mengganggu kandungan nutrisi yang terdapat dalam ransum (Arif, 2010).

Metode pembuatan MnB lazim dilakukan dengan metode panas yaitu pemasakan molases sebelum pencampuran dengan bahan lain. Molases yang dipanaskan dengan suhu $40^{\circ} \mathrm{C}$ akan terjadi proses karamelisasi yaitu berkurangnya kadar air didalam molases sehingga akan lebih kental. Molases dengan tekstur kental, apabila dicampur dengan bentonit dan hijauan jagung maka MnB yang dihasilkan akan lebih padat dan keras. Penggunaan molases dengan persentase yang berbeda maka akan menghasilkan kadar air, warna, aroma dan tekstur yang berbeda. Perbedaan tersebut perlu diuji secara fisik dan organoleptik untuk mendapatkan kualitas yang paling baik.

Penelitian ini bertujuan mengevaluasi pengaruh penambahan level molases dengan metode panas terhadap kualitas fisik dan organoleptik dari MnB. Manfaat penelitian yaitu memperoleh data secara kuantitatif mengenai kualitas fisik dan organoleptik dari $\mathrm{MnB}$ dengan pemberian level molases yang berbeda. Hipotesis penelitian yaitu terdapat pengaruh penambahan level molases terhadap kualitas fisik dan organoleptik pada MnB.

\section{MATERI DAN METODE}

Penelitian dilaksanakan pada bulan Juni sampai eptember 2018. Lokasi penelitian yaitu di Kandang Penelitian Kambing Desa Mrunten Wetan, Kecamatan Ungaran Barat dan Laboratorium Teknologi Pakan Fakultas Peternakan dan Pertanian Universitas Diponegoro, Semarang.

\section{Materi}

Materi yang digunakan dalam penelitian adalah molases, hijauan jagung, cangkang kerang darah, cangkang telur, garam, urea dan bentonit.

\section{Metode Penelitian \\ Tahap Pembuatan Multinutrien Blok}

Pembuatan MnB diawali dengan pencucian pada cangkang kerang dan cangkang telur. Cangkang kerang dan cangkang telur dikeringkan di bawah sinar matahari dan ditumbuk agar memudahkan dalam proses penggilingan. Hijauan jagung dipotong menjadi ukuran yang lebih kecil menggunakan mesin 
chopper untuk mempermudah proses penggilingan menjadi bentuk tepung. Hijauan jagung, cangkang kerang dan cangkang telur kemudian dihaluskan menggunakan grinder tiper disk mill. Penimbangan bahan-bahan penyusun $\mathrm{MnB}$ dilakukan sesuai komposisi pada Tabel 1.

Tabel 1. Komposisi Multinutrien Blok Masing-masing Perlakuan

\begin{tabular}{lcccc}
\hline \multirow{2}{*}{\multicolumn{1}{c}{ Bahan Pakan }} & \multicolumn{5}{c}{ Perlakuan } \\
\cline { 2 - 5 } & $\mathrm{T}_{0}$ & $\mathrm{~T}_{1}$ & $\mathrm{~T}_{2}$ & $\mathrm{~T}_{3}$ \\
\cline { 2 - 5 } Molases $^{\mathrm{a}}$ & 0 & 20 & 35 & 50 \\
Hijauan jagung $^{\mathrm{b}}$ & 50 & 40 & 35 & 30 \\
Cangkang kerang $^{\mathrm{c}}$ & 15 & 10 & 6 & 3 \\
Cangkang telur $^{\mathrm{d}}$ & 15 & 10 & 6 & 3 \\
Garam & 5 & 5 & 5 & 3 \\
Urea & 5 & 5 & 4 & 4 \\
Bentonit & 10 & 10 & 9 & 7 \\
Jumlah & 100 & 100 & 100 & 100
\end{tabular}

Keterangan : abcd : Kadar BK; a : 71,64\%; b : 84,85\%; c : 99,31\%; d : 98,74\%

Molases dipanaskan selama 10 menit dengan suhu $40^{\circ} \mathrm{C}$ dan diaduk terus menerus agar molases tidak gosong. Bahan penyusun $\mathrm{MnB}$ dicampur di dalam ember. Pencampuran bahan dilakukan dengan menuangkan bahan dengan proporsi terbesar kemudian berlanjut diikuti bahan dengan proporsi paling rendah. Bahan dicampur hingga homogen, kemudian molases dituangkan sedikit demi sedikit sambil terus diaduk dengan bahan lainnya hingga homogen dan tidak terjadi penggumpalan. Proses pencetakan MnB dilakukan menggunakan paralon dengan ukuran yang sama. Multinutrien blok diangin-anginkan di ruangan terbuka di bawah naungan.

\section{Koleksi data}

Parameter yang diamati yaitu kualitas fisik yang meliputi kadar air dan kualitas organoleptik yang meliputi warna, tekstur dan aroma. Pengujian organoleptik berdasarkan metode Fathia (2006) yaitu dilakukan dengan bantuan 20 panelis untuk memberikan skor pada masing-masing perlakuan.

1. Kadar air

Pengujian kadar air dilakuan dengan cara mengsterilkan Crucible Porcelain (CP) selama 1 jam sebanyak 16 buah dan diberi tanda sesuai perlakuan dan ulangan. Eksikator CP selama 15 menit, kemudian ditimbang. Sampel MnB dari setiap perlakuan dan ulangan yang telah di angin-anginkan, ditimbang sebesar $1 \mathrm{~g}$ dan dimasukan kedalam CP. Crucible Porcelain yang telah berisi sampel kemudian dilakukan pengovenan minimal 6 jam sampai kadar air konstan, lalu menimbang kembali dan dicatat hasil akhirnya. Perhitungan kadar air dapat dihitung menggunakan rumus sebagai berikut :

$$
\frac{(\text { Berat CP }+ \text { Berat Sampel })-\text { Berat setelah Oven }}{\text { Berat Sampel }} \times 100 \%
$$

2. Uji organoleptik

Tahap pengujian organoleptik menggunakan panelis semi terlatih sebanyak 20 orang untuk memberikan skor pada masingmasing perlakuan. Skor penilaian MnB dapat dilihat pada Tabel 2.

\section{Analisis Data}

Penelitian dilakukan menggunakan rancangan acak lengkap dengan 4 perlakuan penambahan level molases. Perlakuan yang diberikan yaitu :

T0 : Tanpa penambahan molases ( $0 \%$ molases) T1 : Penambahan molases sebanyak $20 \%$ dari bahan kering $\mathrm{MnB}$

T2 : Penambahan molases sebanyak 35\% dari bahan kering $\mathrm{MnB}$

T3 : Penambahan molases sebanyak 50\% dari bahan kering $\mathrm{MnB}$

Semua data yang diperoleh kemudian diolah dan dianalisa menggunakan uji ANOVA, jikadiperoleh hasil yang signifikan maka dilakukan Uji Jarak Berganda Duncan. 
Tabel 2. Penilaian Kualitas Organoleptik Multinutrien Blok

\begin{tabular}{clc}
\hline \multicolumn{1}{c}{ Kriteria } & Skor \\
\hline Warna & \\
- & Coklat Kehitaman & 4 \\
- & Coklat Gelap & 3 \\
\hline$-\quad$ Coklat Terang & 2 \\
$-\quad$ Coklat Kusam mendekati abu-abu & 1 \\
\hline Tekstur & \\
$-\quad$ Sangat Halus & 4 \\
$-\quad$ Halus & 3 \\
$-\quad$ Kasar & 2 \\
$-\quad$ Sangat Kasar & 1 \\
\hline Aroma & \\
$-\quad$ Sangat Harum & 4 \\
- & Harum & 3 \\
- & Sedikit Harum & 2 \\
- & Tidak Berbau & 1 \\
\hline
\end{tabular}

*Semakin rendah skor maka kualitas MnB semakin buruk.

\section{HASIL DAN PEMBAHASAN}

Berdasarkan Tabel 3. rataan kadar air $\mathrm{MnB}$ pada perlakuan T0, T1, T2 dan T3 berturut-turut adalah 22,02; 20,83; 24,70 dan 27,04\%. Hasil analisis ragam tidak menunjukkan pengaruh nyata penambahan berbagai level molases terhadap kadar air MnB. Kadar air MnB pada level molases 20\% (T1) lebih rendah dibandingkan dengan yang tanpa molases (T0), namun setelah diuji statistik tidak menunjukkan hasil yang signifikan. Hal tersebut dapat terjadi karena sifat dari molases dan sebagai perekat dalam pembuatan $\mathrm{MnB}$. Molases yang telah dipanaskan dengan suhu $40^{\circ} \mathrm{C}$ selama 10 menit juga berpengaruh terhadap kandungan air didalam $\mathrm{MnB}$, karena mengalami peristiwa karamelisasi. Gautama (2016) menyatakan bahwa tetes tebu atau molases merupakan bahan organik yang mudah menguap dan reaksi antara molases dengan bahan berasal dari tanah contohnya bentonit akan menghasilkan panas sehinga kandungan air dalam molases berkurang.

\section{Warna}

Berdasarkan Tabel 3. menunjukkan bahwa rataan skor warna $\mathrm{MnB}$ pada $\mathrm{T} 0, \mathrm{~T} 1, \mathrm{~T} 2$ dan $\mathrm{T} 3$ berturut-turut adalah 1,$71 ; 2,09 ; 3,01$ dan 3,99. Hasil analisis ragam menunjukkan penambahan molases berpengaruh nyata $(\mathrm{P}<0,05)$ terhadap kualitas warna pada Multinutrien Blok. Hasil ratarata menunjukkan bahwa T3 memiliki angka yang paling tinggi. Hal ini menunjukkan bahwa penambahan molases dengan taraf 50\% menyebabkan terjadinya perubahan warna menjadi lebih pekat. Semakin banyak level molases yang ditambahkan mengakibatkan penyerapan molases yang semakin banyak dan menyebabkan terjadinya perubahan warna Multinutrien Blok menjadi lebih pekat. Hal ini sesuai dengan pendapat (Widiastuti, 2013) yang menyatakan bahwa semakin banyak molases yang terserap kedalam bahan berpengaruh terhadap warna bahan menjadi lebih kehitaman.

Faktor yang mempengaruhi warna pada Multinutrien Blok yaitu kepekatan warna dari molases yang digunakan. Menurut Pujaningsih et al. (2018) menyatakan bahwa warna molases dapat dipengaruhi dari siklus pemurnian tebu, sehingga semakin sering tebu dimurnikan maka molases yang dihasilkan akan lebih berwarna hitam pekat. Molases selain sebagai alat perekat antara satu bahan pakan dengan bahan lainnya juga berperan penting dalam pemberian warna pada Multinutrien Blok. Perubahan warna pada Multinutrisi Blok kurang berpengaruh terhadap palatabilitas ternak, akan tetapi menjadi pertimbangan peternak sebagai konsumen, berdasarkan atas evaluasi warna dalam memilih pakan (Ningsih, 2010 dalam Widiastuti, 2013).

\section{Tekstur}

Rataan skor tekstur Multinutrien Blok pada T0, T1, T2 dan T3 berturut-turut adalah 1,76; 2,06; 2,16 dan 3,55. Hasil analisis ragam menunjukkan bahwa penambahan berbagai level molases berpengaruh nyata $(\mathrm{P}<0,05)$ terhadap tekstur Multinutrien Blok. Hasil rata-rata menunjukkan bahwa T3 memiliki nilai tekstur yang paling baik yaitu sangat halus. Tekstur yang sangat halus dapat dipengaruhi oleh komposisi hijauan pada penyusunan MnB. Komposisi hijauan pada T3 mengalami penuruan sebesar $20 \%$, sehingga hal tersebut mengakibatkan konsistensi $\mathrm{MnB}$ menjadi lebih lunak atau lembek. Kualitas tekstur MnB dipengaruhi oleh bahan penyusunnya terutama pada 
kandungan serat kasar dan penambahan molases yang digunakan. Hal tersebut sesuai dengan pendapat Widiastuti (2013) yang menyatakan bahwa kualitas tekstur dipengaruhi oleh kadar air dan serat kasar pada pakan, pakan yang mengandung serat kasar tinggi akan membuat tekstur menjadi kasar. Penambahan molases akan membantu bahan pakan untuk saling mengikat satu sama lain, sehingga akan menyebabkan perubahan tekstur MnB menjadi lebih halus. Aslamyah dan Karim (2012) menyatakan bahwa tekstur pakan dapat dilihat dari permukaan pakan yang mulus, berserat atau berlubang. Tekstur pakan behubungan erat dengan palatabilitas ternak. Ternak akan lebih menyukai pakan dengan tekstur yang lunak, karena hal tersebut dapat mempercepat proses penyerapan nutrien.

\section{Aroma}

Rataan skor warna pada Multinutrien Blok pada T0, T1, T2 dan T3 berturut-turut adalah 1,24;
1,94; 2,16 dan 3,32. Hasil analisis ragam menunjukkan bahwa penambahan berbagai level molases berpengaruh nyata $(\mathrm{P}<0,05)$ terhadap aroma MnB. Penambahan level molases yang berbeda antar perlakuan menimbulkan aroma yang sangat berbeda pada MnB. Aroma MnB yang baik memiliki aroma segar cenderung wangi dan tidak tengik. Utomo (2010) menyatakan bahwa aroma pakan yang segar akan meningkatkan konsumsi oleh ternak ruminansia. Faktor yang mempengaruhi aroma pakan yaitu bahan baku, lama penyimpanan dan kandungan nutrisi dalam pakan tersebut. Widiyastuti et al., (2004) menyatakan bahwa aroma pakan dipengaruhi oleh kandungan lemak, protein dan kadar air pada pakan. Perubahan aroma pada Multinutrisi Blok berpengaruh terhadap palatabilitas ternak, dan juga menjadi pertimbangan peternak sebagai konsumen, berdasarkan atas evaluasi aroma dalam memilih pakan (Ningsih, 2010 dalam Widiastuti, 2013).

Tabel 3. Rataan nilai kadar air, warna, tekstur dan aroma pada Multinutrient Blok dengan Level Molases yang Berbeda

\begin{tabular}{ccccc}
\hline \multirow{2}{*}{ Perlakuan } & \multicolumn{4}{c}{ Parameter } \\
\cline { 2 - 5 } T0 & Kadar Air & Warna & Tekstur & Aroma \\
\cline { 2 - 5 } T1 & 22,02 & $1,71^{\mathrm{d}}$ & $1,76^{\mathrm{c}}$ & $1,24^{\mathrm{c}}$ \\
T2 & 20,83 & $2,09^{\mathrm{c}}$ & $2,06^{\mathrm{bc}}$ & $1,94^{\mathrm{bc}}$ \\
T3 & 24,70 & $3,01^{\mathrm{b}}$ & $2,16^{\mathrm{b}}$ & $2,16^{\mathrm{b}}$ \\
\hline
\end{tabular}

Keterangan : Superskrip yang berbeda pada kolom yang sama menunjukkan perbedaan nyata $(\mathrm{P}<0,05)$

\section{KESIMPULAN}

Simpulan dari penelitian ini adalah penambahan level molases sebesar $50 \%$ menghasilkan kualitas fisik dan organoleptik paling baik pada pembuatan Multinutrien Blok dengan metode panas.

\section{REFERENSI}

Arif, Z. 2010. Pengaruh Binder Molases dalam Complete Calf Starter Bentuk Pellet terhadap Konsentrasi Volatile Fatty Acid Darah dan Glukosa Darah Pedet Prasapih. Fakultas Peternakan Universitas Diponegoro, Semarang. (Skripsi).

Aslamyah, S., dan M. Y. Karim. 2012. Uji organoleptik, fisik dan kimiawi pakan buatan untuk ikan bandeng yang disubstitusi dengan tepung cacing tanah (Lumbricus sp.). J. Akuakultur Indonesia. 11 (2): 124-131.
Gautama, G. 2016. Perbaikan tanah labil dengan menggunakan mineral kapur sebagai pendukung pondasi dasar jalan raya. J. Kelitbangan. 4 (1): 63-71.

Preston, T. R. dan R. A. Leng. 1987. Matching Ruminant Production Systems with Avaible Resources in The Tropics and Sub-Tropics. Penambul Books. Armidale.

Pujaningsih, R. I., B. I. M. Tampoebolon, Widiyanto dan D. W. Harjanti. 2018. Evaluation of the Effectiveness of the Use of Papaya Fruit Latex in Making Herbal Medicated Multinutrition Block as a Local Goat Feed Supplement. Animal Production. 20 (1): 39-44.

Putri, H. A. 2006. Fermentabilitas dan Kecernaan in vitro Ransum yang diberi Urea Molasses Multinutrient Block atau Suplemen Pakan Multrinutrien. Fakultas Peternakan Institut Pertanian Bogor, Bogor. (Skripsi).

Tanwar, P. S., Y. Kumar dan R. S. Rathore. 2013. Effect of urea molases mineral block (UMMB) 
suplementation on milk production in buffaloes under rural management practices. Rural Agric. Res. J. 13 (2): 19 - 21.

Utomo, A. J. 2010. Palatabilitas Serta Rasio Konsumsi Pakan dan air Minum Kelinci Jantan Lokal Peranakan New Zealand White yang diberi Pellet atau Silase Ransum Komplit. Institut Pertanian Bogor, Bogor. (Skripsi).
Widiastuti, R. 2013. Kualitas Pellet berbasis Sisa Pangan Foodcourt dan Limbah Sayuran Fermentasi sebagai Bahan Pakan Fungsional Ayam Broiler. Universitas Diponegoro, semarang. (Tesis).

Widiyastuti, T., C. H. Prayitno dan Munasik. 2004. Kajian kualitas fisik pellet pakan komplit dengan sumber hijauan dan binder yang berbeda. Animal Production. 6 (1): 43-48. 